\title{
On the Education of Girls at the Beginning of the 20th Century as Described in the Journal "Świat Kobiecy"1
}

\begin{abstract}
This paper presents the issue of the education of girls as described in the weekly titled "Świat Kobiecy" (Women's World), published in 1905-1906 by Zjednoczone Koło Ziemianek (the United Landladies' Association). Analysis of 104 issues of that journal showed that it believed in the great importance of not only learning how to read and write, but also of the further education of women. It showed solutions adopted in that area in European countries and, on the other hand, proposed various ways to gain an education in Poland, describing specific types of schools and their locations. For the daughters of landowners, it recommended mainly occupational schools. It also provided detailed advice concerning the organization of home schooling to mothers of young girls who could not be educated in institutions for various reasons. For talented girls interested in their own intellectual development and having the necessary funds, it proposed secondary and university education. The approach of the editors of "Świat Kobiecy" fits the tendency of discussions concerning the education of women held at the beginning of the 20th century.
\end{abstract}

Keywords: education of girls, occupational schools, secondary schools and universities, “Świat Kobiecy” journal (1905-1906).

\footnotetext{
* University of Lodz, Faculty of Educational Sciences, Department of the History of Education and Pedeutology.

Article Received: February 11, 2020; Accepted: March 19, 2020.

1 Scientific work financed under the programme of the Ministry of Science and Higher Education under the name "Paths to Independent Poland" in the years 2018-2023; project number 01SPN 170020 18; financing amount: PLN 751222.
} 


\title{
O kształceniu dziewcząt na początku XX wieku w przekazie periodyku „Świat Kobiecy”
}

\begin{abstract}
Abstrakt
Artykuł prezentuje problem edukacji dziewcząt na łamach tygodnika „Świat Kobiecy”, wydawanego w latach 1905-1906 przez Zjednoczone Koło Ziemianek. Analiza 104 numerów tego pisma wykazała, że przywiązywało ono dużą rolę nie tylko do alfabetyzacji, ale do ich dalszego kształcenia. Z jednej strony ukazywało rozwiązania przyjmowane $\mathrm{w}$ tym zakresie $\mathrm{w}$ krajach europejskich, $\mathrm{z}$ drugiej proponowało różne drogi zdobywania wiedzy na gruncie rodzimym, wskazując na konkretne typy szkół i ich zlokalizowanie. Dla córek włościańskich polecało głównie szkoły o charakterze zawodowym. Matkom młodych ziemianek, które z różnych względów nie mogły pobierać nauki w placówkach instytucjonalnych, udzielało dokładnych porad organizowania nauki domowej. Zdolnym i zainteresowanym własnym rozwojem intelektualnym dziewczętom, posiadającym niezbędne środki materialne, proponowało kształcenie na poziomie średnim, a także w szkolnictwie wyższym. Stanowisko redakcji „Świata Kobiecego” wpisuje się w nurt prowadzonych na początku XX w. dyskusji nad edukowaniem młodych kobiet.
\end{abstract}

Słowa kluczowe: edukacja dziewcząt, szkolnictwo zawodowe, średnie i wyższe, czasopismo „Świat Kobiecy” (1905-1906).

\section{Introduction}

The liberalization of the regulations on press publishing in the Kingdom of Poland, signs of which could be observed as early as 1904, resulted in an increase in the number of new titles in the following years, ranging from political publications, through the socio-cultural and literary, to satirical ones. There was also the development of magazines with diverse ideological messages, addressed directly to women (Myśliński 1988: 61-64; Franke 1999: 197-198; Franke 2000: 146-155; Zaleska 1938). One of the periodicals created during this revolutionary period was the weekly "Świat Kobiecy" (Women's World), published in Warsaw from January 7 , 1905. Its subtitle indicated that the magazine would deal with issues related to all areas of women's work, literature, art and farming. Maria Karczewska, a journalist and educational activist in peasant communities, became the editor-inchief and publisher. Initially, no information was provided about whose press organ the magazine was, although it informally appeared on behalf of the 'Delegacji Gospodyń Wiejskich' (Rural Housewives' Delegation), later renamed the 'Koło Gospodyń Wiejskich' (Rural Housewives' Circle) (Kostrzewska 2007: 92). From 
December 16, 1905, it was officially stated on the title page that the magazine represented the United Landladies' Association².

In the first issue of "Women's World" it was declared that it would be guided by the slogan: "Look for new roads...", which was treated as a call and at the same time a challenge for readers: "So that - as it was written - looking for a road to their work, they would not follow the beaten paths, turning in smooth and comfortable, but narrow circles; but with thought, endeavour and desire, they would go further, wider and deeper - and strive only where thought, deed and heart were needed" (Od Redakcji: 1). On the one hand, the magazine's columns were filled with regularly appearing headings, such as "Review of women's activities", "From the moment", "Between us", "Information department", "From the week", "Submitted", "Editorial responses", on the other - articles on broadly understood social, economic, and educational issues, presented the literary output of Polish and foreign writers.

After two years of functioning, "Women's World" ceased to exist. The reasons for closing the magazine are ambiguous. Research in this area conducted by Ewelina Kostrzewska indicates that the difficult financial conditions cited by the editors were not the main reason for withdrawing from further editions, given that at the beginning of 1907 a new publication appeared under the auspices of the United Landladies' Association - the weekly 'Polish Fief'. The more convincing version suggests that the discontinuation of the title was due to its placing too high demands on its readers, consisting in promoting efforts to bring various types of help to people from the lowest spheres, and above all, demanding continuous selfdevelopment from them. Women from the estates expected "easier" content that would introduce them to the world of fashion news, recipes and religious stories (Kostrzewska 2007: 97-101).

Regardless of the reasons for the liquidation of "Women's World", analysis of its 104 issues shows that it was programmatically close to issues of the education of girls. This is evidenced by the more than sixty texts published in the magazine which are intended not only to make the landladies aware of the importance of the problem, but also to involve them in work aimed at encouraging the taking up of institutional education by an increasing number of young females.

\section{Educating girls abroad}

Articles in which accounts of various types of education for girls functioning in European countries were reported were important from the cognitive view. There was a report on the organization of domestic courses for ten to fourteen-year-olds,

\footnotetext{
2 The United Landladies' Association was founded in December 1905 in Warsaw. The Rural Housewives' Circle that was meeting at that time decided to transform into a new organization. It included groups previously operating secretly. ZKZ was registered in March 1906 and its statute was fully legalized by the Russian authorities in March 1907 (Kostrzewska 2007: 28-33).
} 
widely disseminated in Belgium, preparing them to fulfil the duties of mother and housekeeper, not only providing professional knowledge, but emphasizing responsibility and diligent performance of work. These functioned as independent institutions or were located at primary schools. Despite the varied training time, lasting from several months to two years, the study programme always followed both theory (talks about hygiene and the nutritional value of food, tips on economizing expenses and keeping household accounts, explaining the laundry process, cleaning methods, washing and ironing, as well as kitchen rules) and practical exercises (doing cleaning, cooking, baking bread, making butter, washing and folding linen, ironing, repairing clothes, growing vegetables, poultry farming). It was reported that similar women's domestic schools were established in Moravia, the Czech Republic, Austria and Prussia (Kleniewska 1905; Warnkówna 1906). In characterizing the domestic education of girls in Reading, England, initiated by Lady Warwick, her focus on practical preparation in the fields of beekeeping, gardening, and dairy and poultry farming was emphasized. In addition to acquiring knowledge and skills in the selected specific area of agriculture, the students were required to take useful complementary subjects such as accounting, economics, trade, construction and carpentry (Karczewska 1905). The school in New Cross, London, founded under the auspices of the Prince of Wales by the Jewellers' Association, was also discussed, illustrating that its division into female and male sections gave the chance for indigent girls to gain professional education in selected fields - decorative and industrial drawing, trade, dress-making, cutting and sewing, and housework (N.J. 1905). The addresses of vocational horticultural and dairy schools in Germany were also provided, along with their conditions of admission, the duration of tuition and the fees (Szkoły... 1906).

It should be noted that only a few texts showed opportunities for girls to acquire secondary and higher education. Such exceptions were those concerning Finland and Denmark. In an extensive study, it was reported that in the first of those countries, as early as the 1840s regulations came into force allowing the establishment of schools for girls, giving basic general knowledge. Over the course of several decades, the number of these institutions, both government and private, subsidized by the state, increased to 28. Over time, they began to create additional classes extending learning and expanding knowledge, the completion of which gave pupils the right to participate in preparation courses for the final school graduation exam, thus opening the prospect of further education. It turned out that many girls who did not pass this exam, however, participated as free students in lectures at various university faculties, also submitting themselves to the requirements of the university in testing their knowledge. It was their interest in learning that forced the emergence of female secondary education which guaranteed a direct path to higher education. However, the arrival of American ideas on the joint education of both sexes in Finland, which were almost fully accepted by the society because they looked for similarities to the home environment, gathering siblings of different 
sexes under one roof, resulted in the establishment of co-educational secondary schools. And although the natural order for many of their graduates was getting married and starting a family, about 12 percent of young Finns entered a university, staying within its walls a year or a little longer, and many stayed until their studies were complete (Hallsten 1905a, b). In contrast, in the report on education in Denmark, it was explained that young women had already started university studies in 1877 and were still eager to use this opportunity. The beginnings, however, were difficult, because male students behaved with hostility towards their female colleagues, often expressing opposition to their presence in individual faculties. The presented data show that by 1901, 227 women had attended the Universitatis Hafniensis, of whom more than half completed their degree (Kobiety... 1905). In the form of a curiosity, but also as an emerging trend, the request of 60 high school graduates working at the University of Berlin for permission to enrol at German universities as permanent students was mentioned. Similar petitions were submitted by girls who passed the secondary school-leaving examination from Halle, Königsberg, Wrocław and Bonn (Zapisy... 1905).

The descriptions of girls' education in selected European countries, presented by 'Women's World', although only selectively, were intended to show that this question had become the subject of interest of government authorities and a significant part of society, to bring attention to the directions of the development of female education, to stress the need to take up similar initiatives in Poland, and to provide proven designs that could inspire native solutions.

\section{On the possibilities for professional preparation of girls from rural environments}

The magazine tried, requesting the help of its readers, to make at least a superficial diagnosis of the state of literacy of women and men from small communities in the Kingdom of Poland and the access to education of their offspring. The few reports submitted showed that more than half of the adults could not read, and a number of people declaring possession of such skills referred to systematic contact with the prayer book, without revealing that its contents were learnt by heart. They could not cope with texts contained in a prayer book other than their own. There were also villages where only five out of five hundred were literate. For many children, schools were unavailable due to the distance of several kilometres separating them from their place of residence. Attempts to create such facilities were not favoured by views often expressed by parents who claimed that "the child cannot be cleverer than the father" and "the older generation grew up successfully without schools" (Ziemianka 1906). Therefore, in order to, at least slightly, change this state of affairs, the magazine appealed to the landladies that each of them should teach at least one rural child to read and write a year (Karwicka 1905). Undertaking 
educational commitments was particularly important in the case of the female sex, because the purpose of the journal's editors was not only to protect girls from illiteracy, but to instil in them the pursuit of a specific profession. It was written:

In writing intended for women, thought should first and foremost be given to help and advice for peasants who remain in our society at the lowest level of mental development. Nobody cares for them, nobody tries to lift them out of the darkness. They are more likely to raise funds to send their son to study than to educate their daughter. They often give the boy a craft, and the girls (...) they do not try to prepare for future work at all, nor to prepare them to fight the hard conditions of life (Kleniewska 1905: 3).

At the same time, it was realized that the implementation of vocational training for rural girls would not be easy, mainly due to the significant shortcomings of this type of school in relation to the growing need. It was explained that, in terms of numbers, education teaching a specific profession in the Polish lands under the Russian partition occupied one of the last places among the civilized European countries. Therefore, existing facilities were characterized with great accuracy and meticulousness, and newly opened institutions were welcomed. This was done so that information about the existing educational opportunities could reach young peasants through reader-landladies.

The first group of institutions educating girls presented by "Women's World" includes domestic schools, which were intended mainly for the daughters of peasants and the descendants of impoverished nobility, known as those of the field or parish. Their task was to prepare both for running their own future home, and, above all, to improve the culture of its management, and to take up paid work as qualified housekeepers. According to the data obtained by the magazine, the Domestic School opened in Lviv by Helena Szczepanowska, the owner of a boarding house in Nauheim, tried to break with the stereotype of a narrow education, consisting only in learning the art of cooking without taking into account the principles of reasonable nutrition and hygiene of food preparation, and saw the need to focus on all aspects of the household, including sensible management of a modest budget (Bandrowska 1905).

The second Lviv institution mentioned, which certainly drew inspiration for its programme from abroad, was the School of Home Economics, founded by the local "Home Economics" society. The study plan provided for three types of classes: purely domestic activities, theoretical courses combined with practical exercises, as well as lectures and talks. As part of the first of these, students acquired practical skills in cooking, shopping, sewing and repairing clothes, cleaning and tidying up, washing and ironing, preparing budgets and keeping household accounts. In the second area, familiarization with the elements of chemistry useful in everyday life was introduced; botany - learning about the types of fruit trees and shrubs, plants 
that provide feed for animals, vegetables, cereals, medicinal plants and flowers; hygiene - including the hygiene of nutrition, housing, clothing and the body; as well as the duties of the Samaritan, including emergency assistance, dressing, bandaging and caring for patients. Lectures and talks were devoted to the subjects of the history and geography of the Polish lands, social, economic and aesthetic issues. In addition, trips to museums, laboratories, orphanages, children's hospitals; and water, electricity and heating plants were organized once a week (Szkoła gospodarstwa... 1905a, 1905b).

Another example of concern for the education of girls was the Korwin-Piotrowska Domestic School located in Narwiliszki, Lithuania. Built on the site of the ruins of a great Franciscan monastery, surrounded by flowers and a vegetable garden, it was a well-prepared place to organize such education. Poor common girls learned the secrets of tasty cooking, thorough cleaning, proper washing and ironing, sewing, growing vegetables, and looking after animals. With time - as it was emphasized - "they were surprised to compare the work that they had previously done in their households with what they were taught at school" (Węsławska 1906a: 98).

However, the most space in the pages of the periodical was devoted to the domestic-educational Queen Jadwiga School founded in Mirosławice in the Kutno district by the United Landladies' Association. The idea of establishing a new institution for peasants was born in June 1905, and in November 1906 it was officially opened. The financing of the entire undertaking came mostly from membership fees and individual contributions of the members of the Association. Admission was limited to 32 pupils, and the length of study was one year. At the beginning of the school's operation, over 50 girls applied, not only from nearby towns, but also from Łomżyński, Suwałki and Lublin. In the near future it was planned to increase the number of places and establish an orphanage at the school. The educational goal of this establishment was to develop strong, noble characters based on a deep and intelligent faith in the Roman Catholic Church, and a national and cultural awareness. The general education programme provided for teaching religion (but without stimulating false devotion, with a focus on shaping rational Catholics), the history of the Polish nation, writing and reading exercises (to lead to full practice in this field), accounts and accounting, singing and gymnastics. The practical education included all "departments" making up broadly understood rural management. Hence, it was decided to introduce training classes in kitchen management, arranging and using pantries, basements, laundries, garden and apiaries; butter and cheese making; breeding inventories; and hand crafts (Wydziat wychowawczy. Oświata... 1906; Kleniewska 1906; Szkoła Królowej... 1906; MK 1906; Kosmowska 1906; Kretkowska 1906).

Schools for servants were at least partly similar to home economics institutions. The journal once noted the existence of such a place in Warsaw, which operated under the name of St. Zyta's House, and after some time changed into the 
School for the Servants of St. Kinga. It was to take in poor young girls as servants "for everything", because such domestic service was in demand. The establishment of the institution was justified as follows:

What is skilful and serves morality does not need to be displayed; How much unpleasantness can be avoided by having a willing and skilful employee at home every lady knows and values, but in return this employee deserves the right conditions, and above all she must receive a thorough preparation for her profession (Henikowska 1906: 70).

The Warsaw school tried to meet the challenges it faced. It accepted 40 students between the ages of 14 and 18, and taught them cooking, cleaning, ironing, sewing, mending, and proper behaviour. It turned out that interest in such schools was high, because housewives, especially from larger cities, wanted to have qualified servants who could reliably and expertly perform their duties.

Horticultural and agricultural schools were a separate type of institution where girls could receive an education. In their presentation in "Women's World", an important place was occupied by the female horticultural establishment in Chyliczki, near Piastów, created by the Countess Cecylia Plater-Zyberkówna, who provided food and accommodation for her students. It was created thanks to the support of the Women's Horticulture Department of the Warsaw Horticultural Society. During the two-year stay, the girls participated in lectures given by experts on the subject and practical classes organized by four specialist gardeners (Jankowski 1905: 120-121; Brzozowski 1905). Also discussed was the theoretical and practical character of the mixed courses, which existed for many years, for beekeeping and gardening for girls and boys, established at the Beekeeping Museum in Warsaw, run by the Beekeeping and Horticultural Society. Over the course of two years, young participants acquired the necessary knowledge and participated in running an apiary located on site and cultivated the garden, which was located at a considerable distance from the headquarters of the course (Jankowski 1905: 120-121).

The journal also encouraged the education of girls at Miss Bernatowiczówna's Home Economics School, established in a small grange in the Vilnius region, near Święciany. The school had 12 students permanently resident. The eight months of study included the cultivation of plants in hotbeds, the establishment of nurseries of fruit trees and shrubs, using an apiary, drying of vegetables, pig farming and knowledge of dairy work. Schoolgirls were required to take notes of their activities every day so that a horticultural and agricultural 'textbook' could be based on them. It was emphasized with satisfaction that the certificate issued by the school's owner was treated in many places as a guarantee of expertise (Węsławska 1906b).

"Women's World" magazine also mentioned the ability of girls to master craft skills. This was the type of activity carried out by the "Good Shepherd" 
establishment in Warsaw, which focused on providing care to girls from pathological families, aiming to bring them out of misery and moral decline. The main task was to raise the young charges as honest people and employees performing professions most suited to their talents. Therefore, in addition to geography, history, nature, singing and gymnastics lessons, craftwork, basketry, bookbinding and lace making were introduced (Zakład... 1905).

While the "Good Shepherd" taught only vocationally, the Warsaw School of Arts and Crafts of Cecylia Gutowska gave formal qualifications in the chosen profession. Girls were offered the opportunity to learn haberdashery and stylish woodcarving (knives, boxes, platters, frames, etc.), engraving (relief and deep metal engraving, enamelling, incrustation), decorative binding (stationery, chocolate boxes, leather goods), bookbinding, basketry, floriculture, corsetry; dress, coat and underwear making; plain and coloured embroidery. Depending on the chosen course, the education lasted from one to two years (Szkoła artystyczno-rzemieślnicza... 1905).

The provision of information on vocational education for girls was accompanied by a reflection on the material situation of the peasants, which showed that it would be useless to encourage them to acquire a profession if an efficient scholarship system was not created quickly, giving them the opportunity to pay for education and independent living, sometimes in regions remote from where they lived. It was explained that:

Breaking out of the narrow range of mediocrity, we allow you to acquire knowledge, but we do not help with anything! (...) Despite various calls, (...) despite the activities of associations and women's unions, we cannot afford to create social self-help for women in vocational education (Rudnicka 1906: 221-222).

\section{The issue of educating landladies and intellectual young females in secondary and higher education}

Decidedly fewer texts devoted to the education of girls at the secondary level were printed by "Women's World". These were mainly meant for the daughters of betteroff families, coming from spheres higher than the peasantry. The addresses of specific schools were not given, but the focus was on the discussion of what these establishments should be to guarantee females fully-fledged studies in the era of universities opening for women. It was pointed out that the sometimes practised solution of private preparation of girls for the secondary school-leaving exams in a classical boys' gymnasium was a very expensive and difficult route due to the necessity to acquire large amounts of knowledge in a short time. The slowly emerging girls' schools were criticized for being overloaded with learning. The 
activities of a specially appointed Lviv society to create an eight-grade girls' school modelled on the programme at boys' gymnasiums, with only optional subjects such as French, craftwork, drawing and gymnastics added, were given as an example of a reasonable approach to this issue. The implementation of this undertaking resulted in the school obtaining the right to issue certificates equivalent to those of public facilities after a few years (Nauczycielka 1905a). On the other hand, the highschools appointed in Galicia were criticized for their unclear role in educating young females, with the rhetorical question: Who is this school for? (Nauczycielka 1905b).

It should be emphasized that the periodical's position on female secondary education was unequivocal. It was in favour of creating new secondary coeducational schools based on boys' school education programmes in which girls and boys would acquire the same knowledge (M. J. 1906: 125-127; Orsetti 1906a). Among the many justifications for this point of view, it is worth mentioning the opinion of one speaker given at a meeting of the United Landladies' Association:

Therefore, joint mental work bringing together two worlds separate today, can only positively affect both sides. Women educated according to men's school programmes and with the agreement of men (...) having acquired basic and lasting knowledge will be rid of dilettantism and gain the opportunity to get a good education. (...) By constantly interacting with men they will develop energy, will and a willingness to act. From an early age, men will learn to value their work companions, learn to look at women as equals, because equally active and useful members of society (M. J. 1906: 126).

Although "Women's World" did not often accept the custom of home teaching, prevailing not only among landowners, but also town-dwellers, it made an exception for children who were sick, of poor health, nervous, or physically handicapped, for whom leaving the family was almost impossible. To give them a chance to get a good secondary education, it systematically published a series of tips under the common title: "A guide for mothers who want to educate their daughters at home up to the age of 16". It included: a detailed 10-year educational programme with the division of subjects for each year of study, and a weekly distribution of the implementation of learning material, including morning and afternoon classes, methodological remarks, and advice on the selection of teachers, purchase of textbooks and teaching aids. In the final part, it was explained that ten years of home schooling, if it were properly and thoroughly conducted, served as preparation for further education at the universities in Krakow or Lviv or in other European countries. They were also encouraged to consider institutions that provided more practical and specialist knowledge and to participate in summer courses in foreign languages (Żupowska 1905a-i; 1906a-h). 
Similarly to girls' secondary education, their participation in higher education was relatively low. The opinion was expressed several times that young women have the right to university studies. It is clear from the report on the proceedings of the Educational Section of the United Landladies' Association that they were in favour of taking all available measures to facilitate the entry of talented girls to higher education institutions (Wydział wychowawczy. Kształcenie... 1906). There were voices that clearly indicated the losses suffered by society when a woman capable of higher academic work deals only with the household (Orsetti 1906b). Higher education, not necessarily acquired at recognized universities, was treated as a necessary basis for engaging in public life. For these reasons, an attempt was made to sketch the most appropriate university programme preparing women for a full role. It was supposed to be a general university education complete with humanistic, scientific and social knowledge, with lectures on jurisprudence and the science of the state. It was considered that: "Only an enlightened woman, a thoroughly educated woman, will be a useful member of the community, where matters of universal good are concerned" (Przewóska 1905: 417).

For girls who decided to go and study, the journal published an interesting article that contained dilemmas that each of them had to face. She had to consider: first of all, what is the purpose of the trip - to enrich her own knowledge or will it be treated as a "fashionable sport" to bring the power of hitherto unknown experiences; secondly, which university to choose - domestic in Krakow or Lviv or foreign in Germany, Switzerland, France, Sweden, England or Denmark; thirdly - whether the basic feature of the student interested in studies is perseverance in pursuit of the goal or quick discouragement at the multitude of duties; fourthly - at what level does she have knowledge of a foreign language, does this skill require improvement; fifthly, whether she can overcome the unfavourable attitude of lecturers at universities towards girls or will she show weakness leading to her leaving the university; and sixthly, whether one should get married during studies or postpone this decision (Orsetti 1905a; 1905b).

\section{A few words to finish}

To sum up, one should express the view that, when addressing the issue of girls' education, "Women's World" joined the nascent trend of making changes in thinking about education, leading to the modernization of existing behaviour in this area. This attitude represented by the editors of the magazine was not isolated. Many socio-cultural, political-social or scientific-literary magazines, such as "Ster", "Ziemia Kielecka”, "Przegląd Społeczny", "Wieś Ilustrowana”, "Myśl Polska”, "Posiew”, and dozens of others, raised the importance of teaching the youngest generation of Poles, in particular emphasizing the issue of female education. The emerging new view on the need to accelerate the literacy of society and increase further education 
throughout the turn of the nineteenth and early twentieth centuries was part of a broader European context, where trends for disseminating education and acquiring knowledge at subsequent levels of education appeared much earlier, on the other hand - it was associated with hopes, mainly during the 1905 revolution, for the speedy regaining of independence, which required the necessary preparation of society for future changes.

Two conclusions are clear from the analysis of these writings. On the one hand, they focused mainly on female vocational education, which is not surprising, since reader-landladies living on estates outside cities had the closest contact with the local population, which meant that they could have a significant impact on it. On the other hand, the content of articles devoted to the opportunities for young peasants to gain a profession shows that the choice of education in this field was significantly limited, because it was restricted to four types of educational establishments home economics schools, servants' schools, horticultural and agricultural schools, and craft schools. In addition, it is worth mentioning that the magazine's focus on promoting the teaching of rural girls, rather than those from other environments, resulted from the belief that amongst intelligent middle-class landowners, unlike the masses, there existed more awareness of the need to educate their daughters.

\section{References}

Bandrowska M. (1905) Szkoła gospodarstwa domowego, "Świat Kobiecy", 11: 122.

Brzozowski S. (1905) Czas już do pracy!, “Świat Kobiecy”, 19: 215.

Franke J. (1999) Polska prasa kobieca 1820-1918: w kręgu ofiary i poświecenia, Warszawa, Wydawnictwo SBP.

Franke J. (2000) Wokół buntu i pokory: warszawskie czasopisma kobiece w latach 1905-1918, Warszawa, IINiSB UW.

Hallsten I. (1905a) Wyższe wykształcenie dziewcząt i koedukacja w Finlandii, "Świat Kobiecy", 2: 14-16.

Hallsten I. (1905b) Wyższe wykształcenie dziewcząt i koedukacja w Finlandii, "Świat Kobiecy", 3: 26-29.

Henikowska L. (1906) Z chwili, "Świat Kobiecy”, 7: 70.

Jankowski E. (1905) Nauka ogrodnictwa, “Świat Kobiecy”, 11: 129-121.

Karczewska M. (1905) Kolegium rolnicze dla kobiet w Anglii, "Świat Kobiecy", 31: 353-354. 
Karwicka J. (1905) Zaniedbani, "Świat Kobiecy”, 14: 152.

Kleniewska M. (1905) Potrzeby naszych włościanek, “Świat Kobiecy”, 1: 3.

Kleniewska M. (1906) Szkoła Królowej Jadwigi, “Świat Kobiecy”, 37: 385.

Kobiety w Danii (1905), “Świat Kobiecy”, 19: 217.

Kosmowska J. (1906) Sprawozdanie ze stanu funduszów i dzieje powstania Szkoły im. Królowej Jadwigi w Mirosławicach, "Świat Kobiecy", 51-52: 499-501.

Kostrzewska E. (2007) Ruch organizacyjny ziemianek $w$ Królestwie Polskim na początku XX wieku, Łódź, Wydawnictwo Naukowe Ibidem.

Kretkowska M. (1906) Program szkoły gospodarczej im. Królowej Jadwigi w Mirosławicach, "Świat Kobiecy", 51-52: 501-503.

Myśliński J. (1988) Prasa polska $w$ dobie popowstaniowej in: J. Łojek, J. Myśliński, W. Władyka, Dzieje prasy polskiej, Warszawa, Wydawnictwo Interpress: 49-89.

M. J. (1906) Słów parę o koedukacji odczytanych w Kółku Ziemianek, "Świat Kobiecy", 12: 126 .

M. K. (1906) Otwarcie szkoły w Mirosławicach, "Świat Kobiecy", 46: 457-458.

N. J. (1905) Szkoła uniwersalna, "Świat Kobiecy", 19: 216-217.

Nauczycielka (1905a) Gimnazja żeńskie w Galicji, “Świat Kobiecy”, 18: 202-203.

Nauczycielka (1905b) Licea żeńskie w Galicji, “Świat Kobiecy”, 30: 345-346.

Od Redakcji (1905) „Świat Kobiecy”, 1: 1.

Orsetti M. (1905a) Parę słów o wszechnicach dla niewiast w kraju i zagranica, "Świat Kobiecy", 22: 248-249.

Orsetti M. (1905b) Parę słów o wszechnicach dla niewiast w kraju i zagranica, "Świat Kobiecy", 23: 261-262.

Orsetti M. (1906a) Luźne uwagi o wychowaniu dziewcząt, "Świat Kobiecy", 28: 314-315.

Orsetti M. (1906b) Luźne uwagi o wychowaniu dziewczq̨t, “Świat Kobiecy”, 27: 309.

Przewóska M. Cz. (1905) Z postępem, “Świat Kobiecy”, 36: 417. 
Rudnicka F. (1906) Kształcenie kobiet naszych, "Świat Kobiecy”, 20, s. 221-222.

Szkoła artystyczno-rzemieślnicza Cecylji Gutowskiej (1905), "Świat Kobiecy”, 39: 458.

Szkoła Królowej Jadwigi (1906), "Świat Kobiecy", 39: 401.

Szkoła gospodarstwa domowego we Lwowie (1905a), "Świat Kobiecy”, 40: 467.

Szkoła gospodarstwa domowego we Lwowie (1905b), "Świat Kobiecy", 41: 481-482.

Szkoły ogrodnictwa i mleczarstwa (1906), "Świat Kobiecy", 38: 399.

Warnkówna J. (1906) Szkoły gospodarcze w Belgii, "Świat Kobiecy”, 45: 452-453.

Węsławska E. (1906a) Szkoła gospodarcza pani Korwin-Piotrowskiej, "Świat Kobiecy", 9: 98.

Węsławska E. (1906b) Szkoła gospodarcza panny Bernatowiczówny, "Świat Kobiecy”, 21, s. 234-237.

Wydział wychowawczy. Kształcenie młodzieży (1906), "Świat Kobiecy”, 14: 158.

Wydział wychowawczy. Oświata ludowa (1906), “Świat Kobiecy”, 14: 156.

Zakład “Dobrego Pasterza” (1905), “Świat Kobiecy”, 25: 289.

Zaleska Z. (1938) Czasopisma kobiece w Polsce: materiały do historii czasopism, rok 1818-1937, Warszawa, Nakładem Wyższej Szkoły Dziennikarskiej w Warszawie: 137.

Zapisy do uniwersytetu (1905), "Świat Kobiecy", 11: 122.

Ziemianka (1906) Co nam daja badania oświaty ludowej, "Świat Kobiecy”, 3-4: 27-31.

Żupowska E. (1905a) Poradnik dla matek pragnacych prowadzić kształcenie swoich córek w domu aż do 16-go roku życia, "Świat Kobiecy", 39: 455-457.

Żupowska E. (1905b) Poradnik dla matek pragnących prowadzić kształcenie swoich córek w domu aż do 16-go roku życia, "Świat Kobiecy", 40: 465-466.

Żupowska E. (1905c) Poradnik dla matek pragnących prowadzić kształcenie swoich córek $w$ domu aż do 16-go roku życia, "Świat Kobiecy”, 41: 478-480.

Żupowska E. (1905d) Poradnik dla matek pragnacych prowadzić kształcenie swoich córek $w$ domu aż do 16-go roku życia, "Świat Kobiecy", 42: 490-491. 
Żupowska E. (1905e) Poradnik dla matek pragnących prowadzić kształcenie swoich córek w domu aż do 16-go roku życia, "Świat Kobiecy", 43: 504-505.

Żupowska E. (1905f) Poradnik dla matek pragnących prowadzić kształcenie swoich córek $w$ domu aż do 16-go roku życia, "Świat Kobiecy", 45: 519-520.

Żupowska E. (1905g) Poradnik dla matek pragnacych prowadzić kształcenie swoich córek $w$ domu aż do 16-go roku życia, "Świat Kobiecy", 46: 531-532.

Żupowska E. (1905h) Poradnik dla matek pragnacych prowadzić kształcenie swoich córek w domu aż do 16-go roku życia, "Świat Kobiecy", 48-49: 550-552.

Żupowska E. (1905i) Poradnik dla matek pragnacych prowadzić kształcenie swoich córek $w$ domu aż do 16-go roku życia, "Świat Kobiecy", 51: 575-576.

Żupowska E. (1906a) Poradnik dla matek pragnacych prowadzić kształcenie swoich córek $w$ domu aż do 16-go roku życia, "Świat Kobiecy", 1: 7-8.

Żupowska E. (1906b) Poradnik dla matek pragnących prowadzić kształcenie swoich córek $w$ domu aż do 16-go roku życia, "Świat Kobiecy", 2: 21-22.

Żupowska E. (1906c) Poradnik dla matek pragnacych prowadzić kształcenie swoich córek $w$ domu aż do 16-go roku życia, "Świat Kobiecy", 3-4: 35-36.

Żupowska E. (1906d) Poradnik dla matek pragnących prowadzić kształcenie swoich córek $w$ domu aż do 16-go roku życia, "Świat Kobiecy", 5: 49-50.

Żupowska E. (1906e) Poradnik dla matek pragnqcych prowadzić kształcenie swoich córek $w$ domu aż do 16-go roku życia, "Świat Kobiecy", 6: 60-61.

Żupowska E. (1906f) Poradnik dla matek pragnacych prowadzić kształcenie swoich córek $w$ domu aż do 16-go roku życia, "Świat Kobiecy", 7: 73-74.

Żupowska E. (1906g) Poradnik dla matek pragnacych prowadzić kształcenie swoich córek w domu aż do 16-go roku życia, "Świat Kobiecy", 9: 96-97.

Żupowska E. (1906h) Poradnik dla matek pragnących prowadzić kształcenie swoich córek $w$ domu aż do 16-go roku życia, "Świat Kobiecy", 11: 121-122. 